\title{
Exploring the Predictive Relationship between Perceived Caring by School Principals and Teacher Absenteeism and Retention
}

\author{
George O. Cunningham, Ed.D. \\ Hampton City Schools \\ 1 Franklin Street \\ Hampton, VA 23669 \\ USA \\ Linda D. Grooms, Ph.D. \\ Regent University \\ 1000 Regent University Drive \\ Virginia Beach, VA 23464 \\ USA
}

\begin{abstract}
Effective school leadership has been ranked the greatest indicator in the hiring and retaining of highly qualified teachers. Considering that the classroom teacher has the highest impact on student academic success, issues such as teacher absenteeism and turnover not only absorb a great deal of principal time and resources, but ultimately encumber the student learning environment. These issues are further exacerbated in urban school divisions, as students often present with higher needs for support socially, emotionally, and academically. Employing the Caring School Leadership Questionnaire, data were gathered from 293 PreK-12 teachers in two urban school divisions located in the southeastern United States. While the results did not reveal a statistically significant prediction of caring school principals on teacher absenteeism, they did indicate that teacher retention could be predicted. The data further suggested the need for reconceptualizing the role of the principal as not only the chief instructional leader, but equally important, the chief moral leader.
\end{abstract}

Keywords: ethic of care, caring school leadership, measuring care in leadership, urban schools, teacher absenteeism, teacher retention, and school principals as moral leaders

\section{Introduction}

Effective school leadership has been ranked the second highest indicator of student academic achievement and the greatest factor in the hiring and retaining of highly qualified teachers (Lynch, 2012; Sammons, Gu, Day, \&Ko, 2011). However, even the best principals who work in urban schools must contend with numerous challenges such as children living in poverty, high student mobility rates, lack of parental support, scarcity of resources, increased student behavioral issues, student disengagement, teacher absenteeism, and high teacher turnover. Through their research on factors contributing to teacher absenteeism in a large urban school division, Miller, Murnane, and Willett (2008) found that teachers with increased stress due to the demands of the job tended to miss more days. Similarly, Hirsch, Emerick, Church, and Fuller (2007), Finlayson (2009), Lynch (2012), and Phillips (2015) concluded that school climate was a common variable among teachers who were frequently absent. Since relationship building is at the heart of the ethic of care, one could hope that principals who lead from this posture would have an impact on lowering teacher absenteeism, while increasing their retention.

In a study on teacher retention as it related to teacher perceptions of administrative support, Boyd, Grossman, Ing, Lankford, Loeb, and Wyckoff (2011) revealed that problematic relationships with administration increased teacher turnover by $44 \%$ even when variables associated with factors concerning urban school environments such as higher proportions of minority students and higher poverty rates were controlled. Later, Gallant and Riley (2014) found that a lack of emotional support garnered from school leadership was a common theme within their phenomenological study on early warning indicators concerning teacher attrition. 
In addition, their findings revealed that a lack of administrative emotional support negatively impacted a teacher's self-esteem and self-worth.

Other factors affected by the relationships teachers have with school leadership include trust and a sense of community. Buber (1958), a Jewish philosopher and a theologian, noted that trust is a natural byproduct of mutually caring relationships between two or more individuals. In addition, he emphasized the importance of educators engaging in meaningful, caring discussions with each other and with students. Emanating from these relationships, comes a sense of belonging and connectedness, (Fromm, 1956; Grooms, 2000; Macmurray, 1961), which typically facilitates a greater sense of community. As this sense of community is developed among teachers and principals, Noddings (2005) further posited that the ethic of care is reciprocated between teachers and their students, thus potentially catapulting student success and academic achievement.

\section{Background/Literature Review}

Miller et al. (2008) postulated that on average, students spend the equivalent of one entire school year without their assigned teacher during the 13 years of compulsory education due to teacher absenteeism. During that time, classrooms are led by substitutes who are most often less qualified in the course content and ill prepared to handle the more challenging students. In addition, teachers are also exiting the profession altogether shortly after becoming employed (Cherian \& Daniel, 2008; Polansky \&Semmel, 2006; Yaffe, 2015). In a study on teaching force attrition, Ingersoll, Merrill, and Stuckey (2014) revealed that $41 \%$ of all teachers entering the profession leave within the first 5 years. These researchers also found that teachers who worked in urban and high-poverty areas had the highest rate of turnover. In contrast, Guarino, Santibañez, and Daley (2006) revealed that major contributing factors to lower teacher turnover rates were better working conditions and a positive school climate, which inherently involves caring.

\subsection{What is Caring?}

Philosophers (Buber, 1958; Fromm, 1956), scholars (Mayeroff, 1971; Noddings, 2005; Pellicer, 2008; Sergiovanni, 1992), and researchers (Beck, 1994; Gilligan, 1982; Vyver, Westhuizen, \& Meyer, 2014a) describe caring as both an action and an ethic. Beck (1994) specifically described caring as a process of incorporating three activities: receiving the viewpoint of another, responding to the awareness brought on by that viewpoint, and remaining in a committed relationship with that individual.

First, to become aware of another person's needs is to have the ability to take on his or her perspective and accept that person unconditionally. Second, caring eventually involves action by the carer compelling a response to the person in need. In fact, responding to needs by caring nurtures a transition to a culture of community and support (Buber, 1958). Third, the process of care involves continuity once a relationship between the carer and the cared for has been established. In other words, commitment to a caring relationship fosters a way of being in communion between two or more people. A choice to commit to care must follow resulting in a reciprocating relationship as the carer and the cared for exchange roles (Noddings, 2005). When looking at care as a process of these three activities, one can visualize the scaffolding approach to the ethic of care.

\subsection{The Ethic of Care}

Carol Gilligan (1982), founder of the ethic of care and a student of Lawrence Kohlberg (1968), argued that his approach was based solelyon the ethic of justice as moral dilemmas or quandaries were viewed as opposing claims by disputing parties. With this perspective, the only resolution would take the form of a verdict with the winner taking all. In contrast, the ethic of care does not view individuals separately with their opposing claims concerning a conflict, but instead acknowledges that they are already in a difficult situation and the resolution will involve compromise or creative problem solving to ensure no one is harmed in the process. While Kohlberg's (1968) theory espoused the desire to meet the expectations of others, it also inferred that maintaining relationships was inferior to the stage of law and order with a concern for social order and individual rights. In contrast, Gilligan (1982) wrote that the ethic of care centers on a "very strong sense of being responsible to the world" (p. 21). Therefore, it is reasonable to conclude that school principals who incorporate this ethic within their leadership style would have a positive impact on their relationships with teachers. 


\subsection{The Role of the Principal}

Just before the turn of the 21 st century, there was a movement to reconceptualize the role of the school principal (Beck, 1994; Noddings, 2005; Purpel, 1989). Sergiovanni (1992), a senior professor at the Center for Educational Leadership in Texas and the director of Trinity's Principal's Center, noted that prior to that time, principals' duties ranged from ensuring the fiscal well-being of their buildings to contending with the bureaucracy of the central office in meeting the multiple deadlines established throughout the school year. Those functions clearly reflected the traditional role of the school principal, which was hierarchical and autocratic in style. This style focused solely on academic outcomes without providing support for the social/emotional well-being of the personnel within their buildings.

On the other hand, with the new reconceptualized role of the principal, there was a call for fostering a school culture balanced with both academic achievement and social/emotional support (Beck, 1994; Glasser, 1998; Noddings, 2005; Pellicer, 2008). Glasser (1998) noted that leaders who utilize empowerment and encouragement by recognizing the need for employees to feel belongingness stimulate a nurturing climate free from coercion. School leaders who recognize the basic needs of love and belonging by practicing the ethic of care may have the most significant impact on creating a nurturing environment within their buildings, thereby mitigating many of the stressors teachers experience, particularly in urban schools. This implies that school principals who facilitate a culture of care for their teachers create and nurture successful learning communities, facilitating environments that tend to reduce teacher absenteeism and increase their retention.

\section{Methodology}

Two research questions catapulted this study:

RQ1: Does perceived caring by principals as represented by its three determinants (psychological, organizational/workplace, and management) significantly predict teacher absenteeism in school divisions located in an urban setting?

RQ2: Does perceived caring by principals as represented by its three determinants (psychological, organizational/workplace, and management) significantly predict teacher retention in school divisions located in an urban setting?

\subsection{Population and Sample}

Located in the southeastern United States, the target population of this study consisted of approximately 3,000 full-time teachers from 10 high schools, 13 middle schools, 43 elementary schools, two Pre-K-8 schools, one Grade 3-8 gifted center, and one Grade 9-12 Career Academy for Aviation across two urban school divisions.

\subsection{Instrumentation}

Developed by Vyver, Westhuizen, and Meyer (2014b) to measure perceived caring of school leadership by their teachers, the Caring School Leadership Questionnaire (CSLQ) is a 59-item instrument employing a 4-point Likert scale from not at all to to alarge extent. Generally taking 10 minutes to complete, the survey is divided into three parts measuring the psychological (i.e., emotional intelligence, empathy, and optimism), organizational/workplace (i.e., physical building and school climate), and management (i.e., empowering, collaborating, supporting, and accessibility) determinants of care separately. Upon the completion of the $C S L Q$, each determinant of care was individually tallied to provide a raw score that falls into one of four categories: low care, average care, above average care, and high care. Along with completing the $\operatorname{CSLQ}$, teachers were asked to self-report the number of discretionary, sick, or professional development days they were absent from the first day of the school year until the time they completed the survey in late spring. In addition, teachers were requested to report their current teaching assignment (preschool, elementary, middle, or high school) and their intention of remaining in their school building for the subsequent year.

\section{Results}

Among the 3,000 teachers who could have participated in this study, 309 responded to the survey resulting in a $10.3 \%$ participation rate. After reviewing the responses to the question regarding the intention to return the following school year, 16 of the 37 cases responding "no" were excluded based on not returning for an external reason such as retirement, a military spouse relocation, a move to lessen the commute time, or a new job with 
increased wages. Among the remaining 293 responses, 3.1\% $(n=9)$ taught preschool, 31.4\% $(n=92)$ taught elementary, 23.5\% $(n=69)$ taught middle, and 42\% $(n=123)$ taught high school.

\subsection{CSLQ Norms and Overall Descriptive Results}

To most appropriately interpret the scores for each determinant of care (i.e., psychological, organizational/workplace, and management), new norms were created for this study using the quartile scores (i.e., low care, average care, above average care, and high care; see Table 1).

Table 1CSLQ Norms Based on Responses to this Study

\begin{tabular}{llll}
\hline \multicolumn{2}{l}{ Raw score totals: Determinants of care } & & \\
\hline Psychological & Workplace & Management & Description \\
\hline$<59$ & $<27$ & $<61$ & Low care \\
$60-77$ & $28-32$ & $62-78$ & Average care \\
$78-93$ & $33-36$ & $79-91$ & Above average care \\
$>94$ & $>37$ & $>92$ & High care \\
\hline
\end{tabular}

Overall, descriptive statistics revealed similarities in days absent reported by teachers and the level of care by the determinants. Teachers reported being absent from work from 1 to 4 school days based on the mean scores for all reported levels of care during the school year (see Table 2).

Table 2Descriptive Statistics for Level of Care by Determinant and Teacher Absenteeism Responses

\begin{tabular}{|c|c|c|c|c|c|c|c|c|c|}
\hline \multirow[b]{2}{*}{ Level of care } & \multicolumn{3}{|c|}{$\begin{array}{l}\text { Psychological } \\
\text { determinant }\end{array}$} & \multicolumn{3}{|c|}{$\begin{array}{l}\text { Workplace } \\
\text { determinant }\end{array}$} & \multicolumn{3}{|c|}{$\begin{array}{l}\text { Management } \\
\text { determinant }\end{array}$} \\
\hline & $M$ & $S D$ & $n$ & $M$ & $S D$ & $n$ & $M$ & $S D$ & $n$ \\
\hline Low care & 2.47 & 1.07 & 75 & 2.41 & 1.19 & 86 & 2.47 & 1.23 & 75 \\
\hline Average care & 2.47 & 1.50 & 66 & 2.61 & 1.22 & 59 & 2.48 & 1.17 & 71 \\
\hline Above average care & 2.54 & .89 & 72 & 2.47 & 1.04 & 59 & 2.78 & 1.17 & 63 \\
\hline High care & 2.64 & 1.27 & 80 & 2.64 & 1.27 & 89 & 2.45 & 1.19 & 84 \\
\hline
\end{tabular}

Note. Teacher absenteeism ranges are $1=0$ days, $2=1-2$ days, $3=3-4$ days, $4=5-7$ days, $5=8-10$ days, and $6=11$ or more days.

With respect to a teacher's intention to return, 75\% $(n=220)$ reported they would return to their current teaching assignment the subsequent school year, while $7.2 \%(n=21)$ reported they would not, and $17.7 \%(n=52)$ were unsure if they would return. Cronbach's alpha values were calculated for the psychological, organizational/workplace, and management determinants and were $.98, .94$, and .98, respectively. Scoring well above the minimum $\geq .70$ (Rovai, Baker, \& Ponton, 2013), the responses in this study demonstrated high internal consistency.

\subsection{Teacher Absenteeism}

A multiple regression was administered to determine if perceived caring by principals as represented by its three determinants predicted teacher absenteeism. The assumption that the residuals were normally distributed was evaluated by the Kolmogorov-Smirnov test and was found not tenable, $\mathrm{D}(293)=.21, p<.0005$. The absence of extreme outliers was evaluated using a boxplot and confirmed, but a visual inspection of the scatter plots demonstrated that there was no correlation among the determinants of care and teacher absenteeism. In addition, the partial regression plots suggested no correlation separately among the three predictor variables and the criterion variable "absent."

The Durbin-Watson statistic of 1.80 suggested that the assumption of independence of observations was tenable. The multiple regression provided no evidence that perceived caring by principals as represented by its three determinants can reliably predict teacher absenteeism, $F(3,289)=.33, p=.80$. Furthermore, after taking this model and transforming the three independent variables into one total variable noted as "perceived caring" by calculating the sum of all the responses also revealed no statistically significant findings. In addition, according to Rovai et al. (2013), issues with high evidence of multicollinearity occur when variance inflation factors (VIF) are above 4 requiring further investigation, while values above 10 require modification as was the case with respect to the psychological and management determinants respectively (see Table 3 ). 
Table 3Coefficients and Collinearity Statistics

\begin{tabular}{lrllllll}
\hline & \multicolumn{2}{l}{$\begin{array}{l}\text { Unstandardized } \\
\text { coefficients }\end{array}$} & \multicolumn{2}{l}{$\begin{array}{l}\text { Standardized } \\
\text { coefficients }\end{array}$} & \multicolumn{3}{c}{ Collinearity statistics } \\
\hline 1 Model & \multicolumn{1}{c}{$B$} & \multicolumn{1}{c}{$S E$} & Beta & \multicolumn{1}{l}{ S } & Sig. & Tolerance & VIF \\
\hline (Constant) & 2.353 & .316 & & 7.454 & .000 & & \\
Psychological & .007 & .009 & .120 & .746 & .456 & .134 & 7.438 \\
Workplace & .010 & .018 & .058 & .532 & .595 & .293 & 3.411 \\
Management & -.009 & .012 & -.134 & -.707 & .480 & .097 & 10.352 \\
\hline
\end{tabular}

Note. Dependent variable $=$ teacher absenteeism.

Interestingly, based on the factor analysis demonstrating clarity of the factor loadings for all three determinants of care, multicollinearity did not appear to be an issue in the original study of the CSLQ (Vyver et al., 2014b).

\subsection{Teacher Retention}

A multinomial logistic regression was utilized to determine if perceived caring by principals predicted teacher retention. During the statistical analysis, a warning was recorded noting there were 543 cells with zero frequencies and unexpected singularities in the Hessian matrix were encountered. According to Ray (2015), one way to contend with the issue of missing data in the dependent variable or a high number of cells that have a zero frequency within a multinomial logistic regression is to collapse the categories within the dependent variable, if possible, to reduce the number of categories and the number of cells in the analysis. Following this suggestion, "no" and "unsure" were collapsed into a single category creating dichotomous dependent variables of "yes" and "no/unsure." This changed the method of analysis from a multinomial to a binomial logistic regression.

The assumptions for the binomial logistic regression were analyzed by first demonstrating linearity of the continuous variables (psychological, organizational/workplace, and management determinants) with respect to the logit of the dependent variable (teacher retention) via the Box-Tidwell (1962) procedure. A Bonferroni correction was applied using all seven terms (psychological, workplace, management, in_pschdet by psychological, in_workdet by workplace, in_mngmtdet by management, and constant) in the model resulting in statistical significance being accepted when $p<.007143$ (Tabachnick \& Fidell, 2014; see Table 4).

Table 4Variables in the Equation

\begin{tabular}{lcccccc}
\hline Variable & B & $S E$ & Wald & $d f$ & Sig. & Exp(B) \\
\hline Step 1 ${ }^{\text {a }}$ Psychological & -.332 & .393 & .715 & 1 & .398 & .717 \\
Workplace & .430 & .684 & .395 & 1 & .530 & 1.537 \\
Management & .622 & .476 & 1.709 & 1 & .191 & 1.862 \\
In_PsychDet by Psychological & .066 & .076 & .758 & 1 & .384 & 1.068 \\
In_WorkDet by Workplace & -.108 & .159 & .468 & 1 & .494 & .897 \\
In_MngmtDet by Management & -.113 & .092 & 1.509 & 1 & .219 & .893 \\
Constant & -6.795 & 3.553 & 3.659 & 1 & .056 & .001 \\
\hline
\end{tabular}

a.Variable(s) entered on step 1: Psychological, Workplace, Management, In_PschDet * Psychological, In_WorkDet * Workplace, In_MngmtDet * Management.

Based on this calculation, the three determinants of care were found to be linearly related to the logit of the dependent variable (teacher retention). As found with the RQ1 results, there were issues with multicollinearity with both the psychological and management determinants of care.During the statistical analysis, the model resulted in a good fit based on the statistical significance found in the Omnibus Tests of Model Coefficients. The Hosmer and Lemeshow test found statistical significance tenable indicating the model was not a poor fit. In addition, the values of the Cox \& Snell $R^{2}$ and Nagelkerke $R^{2}$ signified good model fit was tenable (see Table 5). 
Table 5Omnibus Tests of Model Coefficients

\begin{tabular}{|c|c|c|c|c|}
\hline & & Chi square & $D f$ & Sig. \\
\hline \multirow[t]{3}{*}{ Step 1} & Step & 23.231 & 3 & .000 \\
\hline & Block & 23.231 & 3 & .000 \\
\hline & Model & 23.231 & 3 & .000 \\
\hline \multicolumn{5}{|c|}{ Hosmer and Lemeshow Test } \\
\hline Step & & Chi square & $D f$ & Sig. \\
\hline 1 & & 7.860 & 8 & .447 \\
\hline \multicolumn{5}{|c|}{ Model Summary } \\
\hline Step & & -2 log likelihood & Cox \& Snell $R^{2}$ & Nagelkerke $R^{2}$ \\
\hline 1 & & $305.747^{\mathrm{a}}$ & .076 & .113 \\
\hline
\end{tabular}

a. Estimation terminated at iteration number 4 because parameter estimates changed by less than .001 .

The model explained that $11.3 \%$ (Nagelkerke $R^{2}$ ) of the variance in teacher retention was correctly classified in $75.8 \%(n=222)$ of the cases. In contrast, the baseline model that excluded the three determinants of care would have correctly classified teacher retention in $75.1 \%(n=220)$ of the cases. Regarding sensitivity and specificity of the model, respectively, $96.8 \%(n=213)$ of the teachers who indicated they were returning to their current teaching assignment for the upcoming school year were predicted correctly by the model, while only $12.3 \%(n=$ 9) of the teachers who indicated they were either unsure or not returning to their buildings were correctly predicted (see Table 6). In addition, the positive predictive value was $76.9 \%$ and the negative was $56.3 \%$.

\section{Table 6Classification Table ${ }^{\mathrm{a}}$}

\begin{tabular}{lclll}
\hline & \multicolumn{4}{l}{ Predicted } \\
& \multicolumn{2}{l}{ returnY_N/Unsure } \\
Observed & & .00 & 1.00 & Percentage correct \\
\hline Step 1 returnY_N/Unsure & .00 & 9 & 64 & 12.3 \\
\hline & 1.00 & 7 & 213 & 96.8 \\
\hline Overall percentage & & & & 75.8 \\
\hline
\end{tabular}

a. The cut value is .500 .

The logistic regression model was found to be statistically significant, $\mathrm{X}^{2}(3)=23.231, p<.0005$; however, with high evidence of multicollinearity, the results should be interpreted with caution. Interestingly, upon examining the variables in SPSS, none of the three determinants of care individually were found to be statistically significant (see Table 7).

Table 7Variables in the Equation

\begin{tabular}{cclllll}
\hline & B & $S E$ & Wald & $d f$ & Sig. & Exp(B) \\
\hline Step $1^{\mathrm{a}}$ Psychological & .009 & .018 & .240 & 1 & .624 & 1.009 \\
Workplace & -.035 & .036 & .980 & 1 & .322 & .965 \\
Management & .036 & .024 & 2.341 & 1 & .126 & 1.037 \\
Constant & -1.019 & .588 & 2.997 & 1 & .083 & .361 \\
\hline
\end{tabular}

a. Variable(s) entered on step 1: Psychological, Workplace, Management.

In addition to running a logistic regression using the three independent variables, the summation of each of the cases including psychological, organizational/workplace, and management determinants were computed and transformed into a new variable called "total_scale." In so doing, statistical significance was found both in the model and the predictor variable in the equation, $\mathrm{X}^{2}(1)=21.237, p<.0005$. The model explained that $10.4 \%$ $\left(\right.$ Nagelkerke $\left.R^{2}\right)$ of the variance in teacher retention was correctly classified in $76.8 \%(n=226)$ of cases. Regarding sensitivity and specificity of the model respectively, $97.7 \%(n=215)$ of the teachers who indicated they were returning to their current teaching assignment for the upcoming school year were predicted correctly by the model, while $13.7 \%(n=10)$ who indicated they were either unsure or not returning to their buildings were correctly predicted (see Table 8 ). 
Table 8Classification Table ${ }^{\mathrm{a}}$

\begin{tabular}{lrccl}
\hline & \multicolumn{4}{l}{ Predicted } \\
& \multicolumn{2}{l}{ returnY_N/Unsure } \\
Observed & & .00 & 1.00 & Percentage correct \\
\hline Step 1 returnY_N/Unsure & .00 & 10 & 63 & 13.7 \\
\hline & 1.00 & 5 & 215 & 97.7 \\
\hline Overall percentage & & & & 76.8 \\
\hline
\end{tabular}

a. The cut value is .500 .

In addition, the positive predictive value was $77.3 \%$ and the negative was $66.7 \%$. The variable total_scale encompassing all three determinants of care together showed the odds that teachers would respond "yes" and remain at their original school assignment for the following school year was 1.014 times greater than a teacher responding "no" or "unsure" (see Table 9).

Table 9Variables in the Equation

\begin{tabular}{clllllc}
\hline & B & $S E$ & Wald & $d f$ & Sig. & Exp(B) \\
\hline Step 1 ${ }^{\text {attotal_scale }}$ & .014 & .003 & 20.214 & 1 & .000 & 1.014 \\
Constant & -1.286 & .533 & 5.822 & 1 & .016 & .276 \\
\hline
\end{tabular}

a. Variable(s) entered on step 1: total_scale.

\section{Discussion}

While this study lacked generalizability, it added to the paucity of research concerning the three determinants of care, particularly in the area of teacher retention, while providing recommendations for future research.

\subsection{Teacher Absenteeism}

Surprisingly, the multiple regression revealed there was no evidence that perceived caring by principals as represented by its three determinants can reliably predict teacher absenteeism, $F(3,289)=.33, p=.80$. In addition, the sum of all three determinants was calculated to create one variable, "perceived caring," resulting again in no statistically significant findings.

This finding is contradictory to the literature (Beck, 1994; Noddings, 2005; Sergiovanni, 1992) since the underpinnings of a caring school principal cultivate a nurturing school climate creating an emotional attachment to the vision and mission by the faculty thereby increasing teacher attendance. In addition, considering there is a link to teacher absenteeism preceding an increase in teacher attrition (Pitts, 2010; Steers \& Rhodes, 1978), it had been hypothesized that obtaining statistical significance regarding the predictor variables and both criterion variables was highly likely.

Several mitigating factors could have impacted the results concerning this RQ. First, even though teachers from two urban school divisions were surveyed, there was only a $10.3 \%$ response rate, much lower than Creswell's (2012) suggested 50\% to 75\%. However, in working with populations such as those in the field of education where personnel may be already overwhelmed with survey research invitations, experiencing some degree of nonresponse is to be expected. One compounding factor that perhaps added to the low response was that one of the school divisions approved this study's survey distribution to begin at the onset of their End-of-Course testing schedule, consequently limiting the time teachers had to participate.

Second, in this study, teachers received two identical follow-up emails. Sauermann and Roach (2013) found that the combination of personalizing emails using participants' first names, changing the wording in the reminder or follow-up emails, and including some type of incentive had significant impact on improving participation. Future research could implement these suggestions.

Third, most teachers self-reported they missed 1 to 4 days of school for the academic year. With not much response variation, there may have been an issue with the scale utilized or teachers may not have been entirely accurate as they recalled the number of days they were not in the school building over the specified time.

Finally, this study found high evidence of multicollinearity among the psychological and management determinants suggesting that both determinants may have cross-loaded. 
This lack of clarity was evident when evaluating the differences between the originally configured norms and this study. With a 20-point raw score difference between the ranges for low and average care between the two studies and a 10-point difference in the range regarding above average care, the data revealed a disparity between the two studies concerning these two determinants regarding the levels of perceived care (low, average, above average, and high care). In contrast, norms for the ranges for the organizational/workplace determinant were much closer between the two studies.

\subsection{Teacher Retention}

This study confirmed the prior research of Cherian and Daniel (2008), Sammons et al. (2011), Lynch, (2012), and Louis, Murphy, and Smylie (2016)concerning how the role of school leadership impacts teachers who have considered whether to remain at their current teaching assignment.It also inferentially confirmed the previous research of Corcoran, Walker, and White (1988); Imants and Zoelen (1995); Loeb, Darling-Hammond, and Luczak (2005); and Boyd et al. (2011) that indicated school climate is associated with impacting teacher retention.Since teacher attrition rates continue to occur at higher levels within the first 5 years of entering the profession, especially with high-needs populations as found in urban school divisions, it is imperative that school principals be emotionally attuned to the needs of their teachers (Ingersoll, 2012; Noddings, 1984).

Similarly, principals guided by the ethic of care, view governance through the lens of service rather than power (Sergiovanni, 1992; Vyver et al., 2014a). As Sergiovanni (1992) noted, it is not a matter of hiring additional leadership in the school buildings when improving public schooling, it is about having better leaders who invoke a sense of moral obligation through care.

In addition, buildings that are clean, safe, and inviting demonstrate a principal's moral obligation for safeguarding his or her teachers as well as the students. Based on the questions found in the CSLQ, it was evident that teachers would choose to remain at their current building assignment where school principals incorporated the ethic of care within their governance model.

Although the model displayed statistical significance revealing that school principals who morally reasoned using the ethic of care could predict teacher retention, astonishingly, none of the determinants of care individually displayed statistical significance in predicting teacher retention based on the Variables in the Equation in SPSS until the aggregate for all the item responses in the $C S L Q$ was analyzed.

\subsection{Recommendations for Future Research}

First, in this study, there were high instances of multicollinearity with two of the three independent variables: psychological and management determinants. According to Rovai et al. (2013), conducting a confirmatory factor analysis is a common approach in survey research for determining "if the measures created to represent a latent variable really belong together" (p. 440). Future research is recommended to conduct a confirmatory factor analysis on the responses gathered from this study and comparing them to the results of those found in the original by Vyver et al. (2014b).

Second, while past research (Miller, 2012; Miller et al., 2008) has shown the seriousness of teacher absenteeism especially in urban school environments, no evidence from the current study demonstrated that caring school principals had an impact on this problem. That makes one wonder if there may have been an issue with the scale when measuring for the variable. One way to possibly alleviate this issue and to limit response bias is to avoid using self-reporting measures (Loevinger, 1957).Future research may want to replicate this study but rather than have teachers self-report, coordinate with the school division to obtain their attendance dataset. This would create another set of issues as anonymity would be definitely forfeited.

Third, the only demographic data collected in this study was the level of the teacher's current teaching assignment. Future research is recommended by replicating this study and including additional demographics such as age, sex, ethnicity, and level of education to identify further relationships and trends regarding the responses to the CSLQ and the impact school leaders have on teacher absenteeism and retention rates.

Fourth, future research is recommended in further linking school leaders who practice the ethic of care and its predictive value on school climate. 


\section{Conclusion}

The results from this study strongly suggest that the ethic of care needs to be amalgamated within the instructional components of school leadership programs. Moreover, school divisions should consider providing ongoing professional development as it pertains to the constructs found within the ethic and encourage further reflection on the primary role of the school leader as not only the chief instructional leader, but also the chief moral leader.

\section{References}

Beck, L. G. (1994). Reclaiming educational administration as a caring profession. New York, NY: Teachers College Press.

Box, G. E. P., \& Tidwell, P. W. (1962). Transformation of the independent variables. Technometrics, 4, 531-550.

Boyd, D., Grossman, P., Ing, M., Lankford, H., Loeb, S., \& Wyckoff, J. (2011). The influence of school administrators on teacher retention decisions. American Educational Research Journal, 48(2), 303-333.

Buber, M. (1958). I and thou. New York, NY: Macmillan.

Cherian, F., \& Daniel, Y. (2008). Principal leadership in new teacher induction: Becoming agents of change. International Journal of Education Policy and Leadership, 3(2), 1-11.

Corcoran, T. B., Walker, L. J., \& White, J. L. (1988). Working in urban schools. Washington, DC: Institute for Educational Leadership.

Creswell, J. W. (2012). Educational research: Planning, conducting, and evaluating quantitative and qualitative research (4th ed.). Upper Saddle River, NJ: Pearson Education.

Finlayson, M. (2009). The impact of teacher absenteeism on student performance: The case of Cobb County School District (Master's thesis). Retrieved from Dissertations, Theses and Capstone Projects. (Paper 4).

Fromm, E. (1956). The art of loving. New York, NY: Harper \& Row.

Gallant, A., \& Riley, P. (2014). Early career teacher attrition: New thoughts on an intractable problem. Teacher Development, 18(4), 562-580.

Gilligan, C. (1982). In a different voice: Psychological theory and women's development. Cambridge, MA: Harvard University Press.

Glasser, W. (1998). The quality school: Managing students without coercion [HarperCollins e-books]. Retrieved fromhttps://www.amazon.com/Quality-School-William-Glasser-M-Debook/dp/B003YCOOJO/ref=sr_1_1?ie=UTF8\&qid=1542897269\&sr=8-

$1 \&$ keywords $=$ the + quality + school+william+glasser

Grooms, L. D. (December 2000). Interaction in the computer-mediated adult distance learning environment: Leadership development through online education.(Doctoral dissertation). Retrieved from Dissertation Abstracts International, 61(12),4692A.

Guarino, C. M., Santibañez, L., \& Daley, G. A. (2006). Teacher recruitment and retention: A review of the recent empirical literature. Review of Educational Research,76(2), 173-208.

Hirsch, E., Emerick, S., Church, K., \& Fuller, E. (2007). Teacher working conditions are student learning conditions: A report on the 2006 North Carolina teacher working conditions survey. Retrieved from https://files.eric.ed.gov/fulltext/ED498770.pdf

Imants, J., \&Zoelen, A. V. (1995). Teachers' sickness absence in primary schools, school climate and teachers' sense of efficacy. School Organisation, 15(1), 77-86.

Ingersoll, R., Merrill, L., \& Stuckey, D. (2014). Seven trends: The transformation of the teaching force. Retrieved from http://www.cpre.org/7trends

Ingersoll, R. M. (2012). Beginning teacher induction: What the data tells us. The Phi Delta Kappan, 93(8), 47-51.

Kohlberg, L. (1968). The Child as a Moral Philosopher. Psychology Today, 2(4), 24-30.

Loeb, S., Darling-Hammond, L., \&Luczak, J. (2005). How teaching conditions predict teacher turnover in California schools. Peabody Journal of Education, 80(3), 44-70.

Loevinger, J. (1957). Objective tests as instruments of psychological theory. Psychological Reports, 3(3), 635-694.

Louis, K. S., Murphy, J., \&Smylie, M. (2016). Caring leadership in schools: Findings from exploratory analyses. Educational Administration Quarterly, 52(2), 310.

Lynch, M. (2012). Recruiting, retaining, and fairly compensating our teachers. International Journal of Progressive Education, 8(2), 121-135.

Macmurray, J. (1961). Persons in relation. Amherst, NY: Humanity Books. 
Mayeroff, M. (1971). On caring. New York, NY: Harper \& Row.

Miller, R. (2012). Teacher absence as a leading indicator of student achievement. Retrieved from https://www.americanprogress.org/issues/education/reports/ 2012/11/05/40371/teacher-absence-as-aleading-indicator-of-student-achievement

Miller, R. T., Murnane, R. J., \& Willett, J. B. (2008). Do worker absences affect productivity? The case of teachers. International Labour Review, 147(1), 71-89.

Noddings, N. (1984). Caring: A feminine approach to ethics and moral education. Los Angeles: University of California Press.

Noddings, N. (2005). The challenge to care in schools: An alternative approach to education [Kindle DX version]. Retrieved from Amazon.com

Pellicer, L. O. (2008). Caring enough to lead: How reflective practice leads to moral leadership. Thousand Oaks, CA: Corwin Press.

Phillips, O. (2015, March 30). Revolving door of teachers costs schools billions every year. Retrieved from http://www.npr.org/sections/ed/2015/03/30/395322012/the-hidden-costs-of-teacher-turnover

Pitts, K. L. (2010). Teacher absenteeism: An examination of patterns and predictors (Doctoral dissertation). Retrieved from http://udini.proquest.com/view/teacher-absenteeism-an-examination-goid:305250728/

Polansky, H. B., \&Semmel, M. (2006). Hiring the best and retaining them. School Administrator, 63(8), 46-47.

Purpel, D. E. (1989). The moral \& spiritual crisis in education: A curriculum for justice and compassion in education. Granby, MA: Bergin \& Garvey.

Ray, S. (2015, November 26). Simple methods to deal with categorical variables in predictive modeling. Retrieved from https://www.analyticsvidhya.com/blog/2015/11/easy-methods-deal-categorical-variablespredictive-modeling/

Rovai, A. P., Baker, J. D., \& Ponton, M. K. (2013). Social science research design and statistics: A practitioner's guide to research methods and IBM SPSS analysis (2nd ed.). Chesapeake, VA: Watertree Press.

Sammons, P., Gu, Q., Day, C., \&Ko, J. (2011). Exploring the impact of school leadership on pupil outcomes. International Journal of Educational Management, 25(1), 83-101.

Sauermann, H., \& Roach, M. (2013). Increasing web survey response rates in innovation research: An experimental study of static and dynamic contact design features. Research Policy, 42(1), 273-286.

Sergiovanni, T. J. (1992). Moral leadership: Getting to the heart of school improvement. San Francisco, CA: Jossey-Bass.

Steers, R. M., \& Rhodes, S. R. (1978). Major influences on employee attendance: A process model. Journal of Applied Psychology, 63(4), 391-407.

Tabachnick, B. G., \&Fidell, L. S. (2014). Using multivariate statistics (6th ed.). Essex, United Kingdom: Pearson.

Vyver, C. P., Westhuizen, P. C., \& Meyer, L. W. (2014a). Caring school leadership: A South African study. Educational Management Administration \& Leadership, 42(1), 61-74.

Vyver, C. P., Westhuizen, P. C., \& Meyer, L. W. (2014b). The caring school leadership questionnaire (CSLQ). South African Journal of Education, 34(3), 1-7.

Yaffe, D. (2015). Find, keep, cultivate the best. District Administration, 51(2), 31. 